\title{
Inherited Behaviour in Wilkie Collins's The Legacy of Cain: Victorian Studies and Twenty-First-Century Science Policy Jay Clayton
}

'For twenty years past, my friend, I have been studying the question of hereditary transmission of qualities. ...'

—Wilkie Collins, The Legacy of Cain (1888)

The Victorians knew nothing about genetics, but they had a vigorous discourse about the hereditary transmission of behaviour. Scientists and novelists alike wrestled with the problem of whether 'character' was heritable. Today, for reasons that at first seem entirely unrelated, we are witnessing a resurgence of interest in the biological foundations of character. After some fifty years of ethical doubts about the wisdom of pursuing such avenues of research, the heritability of behaviour is once again a hot topic.

In the biological sciences this renewed interest comes from three main directions: genetics, which garners the lion's share of public attention for its success in identifying genes that are associated with increased probability for a given trait (a success that has accelerated dramatically in the past few years with the advent of genome wide association studies); neuroscience, a diverse field that draws variously on cognitive psychology, linguistics, brain imaging and evolutionary biology; and epigenetics, which is the concern of this article. Because of its focus on non-genetic sources of inherited traits, epigenetics should be of interest to scholars of a period that did not yet understand the genetic mechanism of inheritance.

Epigenetics can be defined as the study of heritable characteristics that have a molecular basis independent of DNA. According to the journal Nature, which ran a special section on the field in May 2007, 'epigenetics is riding a wave of popularity. ${ }^{1}$ Noting that more than 2,500 articles had been published on the subject within the year, the editors of Nature observed that the media portrays epigenetics as 'a revolutionary new science.' 2 Epigenetic changes are crucial for normal cell growth and have long been a topic in developmental biology, but the recent discoveries have to do with how cells can transmit acquired traits to daughter cells through non-genetic modes of inheritance and with evidence that some variations in species may be directed rather than random. Eva Jablonka and Marion J. Lamb have 
summarised the four main contentions of epigenetics in their book Evolution in Four Dimensions (2005):

- there is more to heredity than genes;

- some hereditary variations are non-random in origin;

- some acquired information is inherited;

- evolutionary change can result from instruction as well as selection. ${ }^{3}$

These are disorienting claims, which seem to violate some of the central tenets of genetics and contradict much of what we have learned about Darwinian evolution. They suggest that biological traits can be inherited from sources other than DNA, that natural selection does not arise solely from random mutation, that Lamarckism may have more validity than most of us dreamed, and that evolution at times may be directed toward specific goals. I will explain more of the fundamentals of this new research as I proceed, but first I want to suggest that the interdisciplinary study of the nineteenth century has something valuable to contribute to the public policy debate emerging around this 'revolutionary new science'.

Public perceptions of science play a large role in the policy making process today. ${ }^{4}$ Ethics committees and policy boards recognise that literature, film, and other media shape popular understandings of science and that cultural values are relevant to decisions about scientific policy. Unlike debates over whether culture shapes the findings of science, no one disputes that culture plays a role in matters of science policy. The groups that have the greatest influence on establishing science policy are interdisciplinary committees of researchers and scholars, who hold hearings, sponsor colloquia, and issue recommendations. The participants in this process are drawn from a wide cross-section of the scholarly and professional world: scientists, doctors, lawyers, anthropologists, sociologists, philosophers, and increasingly, theologians. A noticeable absence in these interdisciplinary gatherings, however, is anyone trained to interpret and comment on culture. Scholars of literature, history, art and art history, performance studies, film and theatre are largely missing from the policy making process. This imbalance represents both a problem and an opportunity for humanists. The problem, of course, is that our absence from the room skews the resulting image of culture. The opportunity is for literary and

19: Interdisciplinary Studies in the Long Nineteenth Century, 7 (2008) www.19.bbk.ac.uk 
historical perspectives to begin to affect political and civic decisions more directly than at any time since the nineteenth century.

In the Victorian era, George Eliot, George Henry Lewes, Thomas Huxley, Matthew Arnold, Herbert Spencer, Samuel Butler, August Weismann, and other intellectuals forcefully debated the role of science in society. Many people today are envious of that earlier period, when the literary and scientific spheres were not so profoundly divided. ${ }^{5}$ The split between what C. P. Snow called the 'two cultures' widened throughout much of the twentieth century as disciplinary specialisation became increasingly necessary to scientific research and the humanities developed their own regimes of disciplinary expertise. But nostalgia for a time when science and the humanities constituted one culture does not point the way to overcoming the divide. We cannot return to a previous cultural formation. The gulf between the two cultures is too wide, and no amount of clarity or force of style can heal a breach that is a consequence of some of the largest social and economic trends in the modern world. Until recently, there was little to be done about the situation, but in the last few decades, the relationship of disciplinary expertise to public life has begun to shift.

The chief change in this relationship is the emergence of an influential, semiautonomous zone of activity known as the policy arena. This zone occupies an intermediate position between the disciplinary specialist and the public sphere, mediating even as it formalises the process of speaking out about public issues. The people who gain a voice in this arena are sometimes referred to as policy experts, but the source of their expertise lies in disciplines outside the policy arena. For example, one may get a master's degree or do a post-Doc in health policy, but this credential generally complements rather than replaces the $\mathrm{MD}, \mathrm{JD}$, or $\mathrm{PhD}$ that constitutes the expert's primary qualification. At the higher levels of the policy world, the credential that matters, the ticket that earns one a seat at the table, is scholarly distinction in one's home discipline. The policy process is best described as a transdisciplinary activity since its work is done by ad hoc groups of experts from other disciplines, who come together to forge positions on specific problems. Today, expertise plays its greatest role in public life through the intermediary of

\section{Jay Clayton, Inherited Behaviour in Wilkie Collins's The Legacy of Cain: Victorian} Studies and Twenty-First-Century Science Policy

19: Interdisciplinary Studies in the Long Nineteenth Century, 7 (2008) www.19.bbk.ac.uk 
shifting, transdisciplinary gatherings of specialists, who meet, deliberate and speak in a well-defined set of venues.

To date, few members of the literary, artistic, or historical branches of the humanities have become participants in this process. In The University in Ruins (1996), Bill Readings once lamented that the arts may reflect on the cultural implications of scientific knowledge but that 'such reflections are constitutively cut off from any practical effect. ${ }^{6}$ For most of the twentieth century, this was sadly true. But the growth of the policy arena, with its institutional structures for mediating between 'reflection' and 'practical effect', has changed the rules of the game. It has created a formal mechanism that gives critique at least a chance of having real consequences.

Perhaps the most notable example in the U.S. of turning to literature to stimulate reflection on bioethics occurred in the inaugural meeting of the President's Council on Bioethics, chaired by Dr. Leon Kass, where the Council devoted an entire seminar to discussing Nathaniel Hawthorne's 'The Birth-Mark'. In subsequent sessions, literature continued to receive attention, and the Council eventually released a fat anthology of stories, poems and creative non-fiction ranging from Homer, Ovid, and Shakespeare to Frederick Douglass, Lorrie Moore and Isaac Beshevis Singer. It is impressive to read the musings about literature of this very smart group of doctors, lawyers, geneticists, neuroscientists, political scientists, philosophers and theologians. ${ }^{7}$ Any one of us might wish to be in such a seminar ... and that is part of the point: we weren't. Of the dozens of scholars who met with this commission and discussed the fundamental values of U.S. culture, invoking texts that we study and teach, not one was a scholar of literature or the arts.

Literature is often regarded as the common property of everyone, of course, not the private province of experts. But the issue is not whether Dr. Kass and his colleagues were qualified to discuss a short story without the assistance of literature professors. Rather the issue is whether in a polity where decisions are influenced by the findings of multidisciplinary taskforces of professional experts, our disciplines want to be left out of the process. In a society based on disciplinary structures and the testimony of experts, it is debilitating to be among the disciplines and experts left out in the cold; debilitating for society, not just for us. Philosophers have

19: Interdisciplinary Studies in the Long Nineteenth Century, 7 (2008) www.19.bbk.ac.uk 
established themselves in the policy arena, and so have theologians. Why have the literary, artistic, and historical branches of the humanities gone unheard?

The answers to this question are complex and well-deserving of treatment in another place. Here I intend to focus on possible remedies to the problem, with specific attention to how the study of Victorian literature can contribute instrumentally - not indirectly - to public policy. The solution lies in repositioning our disciplines within the institutional framework of the university and the professional economy of society. For this project to succeed, we do not need to prove that cultural representations of science have important consequences. Nobody disputes that. Rather we need to show that our expertise in analysing those consequences can be of value to policy debates. As experts in our own fields, specialists deeply versed in literature, popular culture and the arts, we can add something distinctive to collaborative research groups and problem-oriented projects. The case will be made by offering what we already do to grant agencies outside the usual handful of humanities foundations, to our colleagues in the sciences who are often required to include an ethics component in their grant applications and almost always call on philosophers or social scientists to provide that component, to conferences in other fields, to journals of public policy, and ultimately, to the commissions that formulate the rules that govern scientific research.

In 2003, Priscilla Wald and I received a grant from the National Human Genome Research Institute, a branch of the U.S. National Institutes of Health, to promote the study of literature and genetics through a multi-university consortium of humanities professors and geneticists, physicians and legal scholars. Our consortium conducted meetings at Vanderbilt and Duke Universities with the goal of developing pedagogical and research methods for using literature and film to explore the ethical and social issues raised by genetics. You can learn more about our project on our web site. ${ }^{8}$ Although our working group focuses on genetics, other literature professors have had similar success in attracting untraditional funding for their research on digital culture, disability issues, the environment, narrative medicine, immigration, poverty, race and sexuality. In the U.K. the climate for grants from the ESRC on policy issues seems to be even more open than in the U.S. My point is that

19: Interdisciplinary Studies in the Long Nineteenth Century, 7 (2008) www.19.bbk.ac.uk 
any topic with significant policy implications for today's society can be made germane to multidisciplinary and trans-institutional groups of scholars, who receive support and present results outside the channels of traditional humanities research.

In the next section I turn to a novel by Wilkie Collins to model a kind of critical practice that could be of interest to the policy community. Exploring how novelists and scientists in the late nineteenth century attempted to cope with notions of inherited behaviour without genetics sheds an interesting light on twenty-firstcentury reactions to the news that acquired characteristics and behavioural traits may be passed on to future generations through mechanisms other than the gene.

\section{I}

The Legacy of Cain (1888), the last novel Wilkie Collins published before his death, is structured as a case study of the respective influences of nature and nurture, to use the terms Francis Galton coined just a few years earlier. The novel tells the story of two sisters raised in the same household, one the adopted daughter of a woman who was executed for murder, the other the biological child of the Reverend Abel Gracedieu and his wife. The central question of the book is whether the daughter of the murderess will reveal a 'hereditary taint' from her mother or whether a loving and religious environment will prove the stronger influence on the child's character. ${ }^{9}$ To complicate the mystery, the minister, after his wife's early death, conceals from everyone that one of the two children was adopted. For much of the novel, the reader is kept guessing about which young lady is the daughter of a murderer. One finds oneself weighing each mental and physical characteristic of the sisters against one's memory of the two mothers, the murderess and the minister's wife.

Let me relieve your suspense. If I don't reveal the sisters' names, I can safely disclose the outcome of this convoluted plot without ruining the novel for anyone who has not read it. The daughter of the murderess does indeed inherit the propensity for murder from her mother, but the daughter of the minister himself is the one who actually attempts to commit a real murder. It is the minister's biological daughter who ends up trying to poison her fiancé. The unexpected twist of having the murderer's daughter resist the temptation to kill and the minister's daughter give

19: Interdisciplinary Studies in the Long Nineteenth Century, 7 (2008) www.19.bbk.ac.uk 
into the same temptation stems from Collins's conviction that the power of maternal inheritance is greater than any influences that descend from the father, through either nature or nurture. This seems paradoxical until one realises that the murderess's daughter inherits both her mother's propensity for violence and her capacity for love, and that it is the latter that wins out in the end.

Collins reveals that the innocent daughter is struggling against an inherited tendency toward murder by a simple novelistic expedient, ready at hand from gothic conventions. When betrayed in love, she finds herself literally possessed by her mother's murderous spirit. The ghost of her mother, in a perverse echo of Dickens's A Christmas Carol (1843), comes to the daughter in her sleep and shows her three different ways she could murder her rival. To make the overpowering force of heredity a bit more plausible, Collins borrows a device from his earlier novel The Moonstone (1868) by having her drink a dose of laudanum before she falls into her somnambulant trance. Nonetheless, when under the influence of what the narrator calls 'the lurking hereditary taint' (LOC 237), the daughter feels overcome by a 'new evil self' (LOC 153), a 'hateful second self' (LOC 223), and a 'horrid transformation of me out of myself' (LOC 215). To dramatise behavioural impulses beyond a person's control, impulses inherited from another rather than a product of one's conscious will, Collins has the daughter become an automaton.

The evil sister, the minister's own daughter, ends up trying to poison her fiancé, for reasons I need not go into other than to say that they stem from her maternal inheritance. When crossed in love, the minister's daughter does not resist the temptation to kill because she has inherited her mother's cold, intellectual disposition. Just as the impulse to love in the first sister is a finer quality she has inherited from her mother, an unfeeling nature is part of the evil sister's maternal legacy. The evil sister is last heard of in America, where she leads a utopian community dedicated to the 'Worship of Pure Reason' and to establishing the 'superiority of woman over man' (LOC 346), a last bit of authorial irony at the expense of the novel's villain and intellectual women generally.

The problem of inherited traits is not allowed to rest there, however. Collins confuses matters by postulating in a few places that there exists an innate quality in womanhood that is independent of both nature and nurture. Critics have attributed

Jay Clayton, Inherited Behaviour in Wilkie Collins's The Legacy of Cain: Victorian Studies and Twenty-First-Century Science Policy

19: Interdisciplinary Studies in the Long Nineteenth Century, 7 (2008) www.19.bbk.ac.uk 
the novel's incoherence to Collins's supposed misunderstanding of Darwin. ${ }^{10}$ As we shall see in the next section, this view is wrong on two counts. First, it is not Darwin whose ideas are being explored in this novel so much as the neo-Lamarckians writing in the 1880s. Second, the confusion in the book does not stem from a faulty grasp of current thinking about heredity but from conventional assumptions about women's roles, assumptions that contradict what the novelist appears to have learned about the inheritance of acquired characteristics.

In several places the narrator affirms his faith that 'There are inherent emotional forces in humanity to which the inherited influences must submit' (LOC 217). These emotional forces do not come from the environment - the minister's careful nurture of his two daughters may have cultivated these positive qualities, but they are, the narrator insists, 'inherent' rather than acquired. In particular, they seem to be inherent in womanhood. The narrator explains why he believes in this 'inherent' force in a long passage dedicated to assessing the possible influences on the good sister's character. While admitting the dominant power of heredity and marking a lesser role for environment, the narrator postulates an independent 'power for Good,' whose origin remains unexplained by either factor. The narrator proposes (comically enough) that the source of this power lies in the onset of puberty. When a girl becomes a woman, her feminine capacity for love protects her. In hindsight, we can identify this mysterious 'power for Good' as a pure emanation of Collins's own cultural presuppositions about gender:

While, therefore, I resigned myself to recognize the existence of the hereditary maternal taint, I firmly believed in the counterbalancing influences for good which had been part of the girl's birthright. They had been derived, perhaps, from the better qualities in her father's nature; they had been certainly developed by the tender care, the religious vigilance, which had guarded the adopted child so lovingly in the Minister's household; and they had served their purpose until time brought with it the change, for which the tranquil domestic influences were not prepared. With the great, the vital transformation, which marks the ripening of the girl into the woman's maturity of thought and passion, a new power for Good, strong enough to resist the latent power for Evil, sprang into being, and sheltered [her] under the supremacy of Love. (LOC 216-17)

Woman's innate power to love seems to exist independent of nature or nurture. Postulating this innate quality in womanhood renders all the forgoing

\section{Jay Clayton, Inherited Behaviour in Wilkie Collins's The Legacy of Cain: Victorian} Studies and Twenty-First-Century Science Policy

19: Interdisciplinary Studies in the Long Nineteenth Century, 7 (2008) www.19.bbk.ac.uk 
analysis of heredity incoherent. Gender assumptions trump everything Collins's knows about nineteenth-century scientific theories of inheritance. If the change brought by time, the great and vital transformation that marks the ripening of the girl into womanhood, is nothing other than puberty, then why did not the other sister find strength in a similar transformation? The answer appears to be simple: the other sister is just too bright. Collins emphasises again and again how much smarter the evil sister is than the good, and her cleverness, inherited from her mother, seems to prevent the ripening of a feminine power for good.

Two conclusions relevant to twenty-first-century science policy may be drawn from this discussion of inherited behaviour in Collins's The Legacy of Cain. (1) Before genetics, the cultural understanding of inheritance made ample allowance for the kind of maternal influences on biological development that epigenetics stresses, and (2) Collins's cultural assumptions about gender overruled his take on the science of the day, wreaking havoc with his novel's theme.

In its very incoherence, Collins's novel has something to teach us about the cultural understandings of inheritance in late-nineteenth-century England. During the mid$1880 \mathrm{~s}$, there was renewed interest in the question of whether acquired characteristics could be inherited. The rise of 'neo-Lamarckism', a term coined in 1885, was visible among intellectuals such as Herbert Spencer, Samuel Butler, and later, George Bernard Shaw. Ranged against them were Francis Galton, Thomas Huxley, H. G. Wells, and most important, August Weismann, whose publications of 1883 and 1885 developed the concept of the "continuity of the germ plasm." ${ }^{11}$ Weismann argued persuasively against the 'transmission of acquired characters' and disputed that 'changes of the organism which result from external stimuli can be transmitted to the germ cells and will re-develop in the next generation' (OH 104). Instead, he maintained that the germ cell 'transfers its hereditary tendencies from generation to generation, at first unchanged, and always uninfluenced in any corresponding manner, by that which happens during the life of the individual' $(O H 69)$, or as we would phrase it today, a person's genotype is inherited from his or her parents and

19: Interdisciplinary Studies in the Long Nineteenth Century, 7 (2008) www.19.bbk.ac.uk 
cannot be affected by changes in the phenotype caused by experience or the environment. Historians of science have identified Weismann's concept as a precursor of what would later become the 'central dogma' of genetics, the principle that information can only flow in one direction, from genes to the proteins that they express. In classical genetics, it was a matter of dogma that no acquired abilities could flow backwards into the DNA of an individual.

Partisans of epigenetics view this decade, the 1880s, as the moment when evolutionary theory took a wrong turn that would lead toward 'genetic centrism' and away from inquiries into developmental biology that might have revealed the possibility that acquired characteristics were heritable. Jablonka and Lamb, like many of their peers, are unabashed neo-Lamarckians, or perhaps I should say postLamarckians, to indicate that they have updated Lamarckian assumptions for the age of genomics.

Collins was clearly familiar with the arguments raging at the time. It used to be commonplace to assert that Collins made 'very little reference to the intellectual currents of his own time, ${ }^{12}$ but this view has been countered in recent years by the research of Jenny Bourne Taylor, Lyn Pykett, and others, who have demonstrated the many ways in which his novels respond to the social and scientific debates of Collins' day. Taylor stresses the novelist's engagement with discourses of degeneration and points to an echo in The Legacy of Cain of Henry Maudsley's work of the 1870 s on inherited vices. ${ }^{13}$ She also notes Collins's familiarity with 'Lamarck's model of willed transformation. ${ }^{14}$ Christopher Kent connects a minor character in the novel, Miss Chance, with Collins's interest in the role of chance in evolutionary theory, and links the narrator, who begins the novel as the governor of a prison, with the theme of hereditary criminality prominent in late-nineteenthcentury social science. ${ }^{15}$ Given what we now know about the extensive preparation Collins made for the writing of his anti-vivisection novel, Heart and Science (1883), it is abundantly clear that the older view of the novelist as out of touch with intellectual debates is wrong. ${ }^{16}$

All the same, I do not want to suggest that Collins's interest in the hereditary transmission of behaviour means his novel anticipates the ideas of twenty-firstcentury epigenetics. That is not my point at all. Rather, I bring up Collins's novel to

19: Interdisciplinary Studies in the Long Nineteenth Century, 7 (2008) www.19.bbk.ac.uk 
show how scientific debates about heritability in this critical decade were translated into other cultural registers.

To look for a Victorian anticipation of epigenetics, I would like to turn to an unlikely source, Francis Galton. Galton was committed to the principle that 'Nature is far stronger than Nurture' in shaping character, ${ }^{17}$ and he inadvertently put the quietus to Darwin's theory of pangenesis, which gave some room for the inheritance of acquired characteristics. Galton's experiments with blood transfusions from white rabbits to grey rabbits proved that the particles Darwin called gemmules could not pass from the blood into the germ line, as Darwin had appeared to suggest. Nonetheless, at the end of the chapter titled 'Nurture and Nature' in his 1883 work Inquiries into Human Faculty and Its Development, Galton makes a surprising concession: 'Nurture acts before birth, during every stage of embryonic and preembryonic existence, causing the potential faculties at the time of birth to be in some degree the effect of nurture. ${ }^{18}$ This sentence blurs the boundaries between nature and nurture in fascinating ways. It grants a biological basis to the influences of the maternal environment, and it opens the door to the possibility that faculties can be inherited from the mother that were not present in the child's DNA. These are two of the central contentions of epigenetics, at least as formulated by Jablonka and Lamb, by the editors of the recent special section of Nature, and by the contributors to the influential anthology, Genes in Development. ${ }^{19}$

The fact that the mother's cytoplasm makes an important contribution to the developing faculties of the embryo was established many decades ago, but epigenetics has given a new twist to this fact. Research on DNA methylation and RNA interference has suggested mechanisms by which heritable information other than DNA can be transmitted not only from cell to cell but from parent to child. These mechanisms can be activated by environmental stress, and if the stressful conditions continue for long enough, these cellular states can become subject to natural selection. This is, in effect, an explanation of how environmental conditions affecting the parent can be passed on to the child. 
A study of Collins, or even of the controversy among nineteenth-century neoLamarckians and their opponents Galton and Weismann, can shed little light on the science of epigenetics. But epigeneticists are not the target audience for this kind of interdisciplinary study of the nineteenth century. Literary scholarship should not expect to affect the practice of science. It is unrealistic to think that scientists will have the time or (professional) interest to explore our research; more important, such an aim misunderstands the kind of the contribution that humanities scholarship might make to the scientific enterprise. If literary study can be of little use to the sciences, it can be of genuine interest to people involved in science policy. As a case study of how scientific developments are mediated by the larger culture, a discussion of Collins may be germane to questions concerning the social, ethical, and cultural implications of epigenetics.

How does one go about making research on nineteenth-century literature useful for a policy discussion? Noting that literature dramatises the issues at stake and enables the public to identify with the consequences of ethical choices is an important first step, of course, but scarcely enough to make a case for extended reflection on literature. A more problematic way to bring literature to bear on contemporary problems is the approach of the President's Council on Bioethics: to insist that literature reveals enduring truths about the human condition. Dr. Kass introduces the Council's anthology with this justification: literature 'can contribute to a richer understanding and deeper appreciation of our humanity, necessary for facing the challenges confronting us in a biotechnical age. ${ }^{, 20}$ This is true in its way, but potentially misleading. After all, literature presents a multitude of perspectives on human nature, even questioning whether there is such a thing. Collins presents woman's capacity for love as one of the 'inherent emotional forces in humanity' (LOC 217) that can counterbalance the effects of heredity. But who among us would be tempted to accept as enduring truths about human nature the gender assumptions that structure Collins's resolution of his story? Who among us would endorse the principle that the possession of a strong intellect in a woman is liable to render her vulnerable to murderous impulses and that a woman's inherent affinity for love may

Jay Clayton, Inherited Behaviour in Wilkie Collins's The Legacy of Cain: Victorian Studies and Twenty-First-Century Science Policy

19: Interdisciplinary Studies in the Long Nineteenth Century, 7 (2008) www.19.bbk.ac.uk 
be the only thing preventing her from giving into a biologically hardwired propensity for homicide?

In opposition to Kass's approach, many humanists would argue that readers learn to think critically about the human condition by situating a literary text in its own historical moment and by attending to the differences as well as the continuities between that time and one's own. Others might suggest that examining the formal complexities of a work of art could potentially undercut the very lessons Dr. Kass seeks to derive from it. In short, most humanists would advocate an approach that was more critical because more alert to historical or formal complications.

To propose that historical or formal sophistication is needed to gauge the relationship of a literary work to political concerns is no news to readers of this journal. But I have a more concrete proposal. Policy makers care deeply about the relationship of science to larger cultural assumptions, and they care about public perceptions of science just as much. Social scientists continually take the temperature of public attitudes about science using statistical measures, but literary and historical study could shed a different kind of light on the question. I suggest that we offer literary study to the policy community as a critical, historical and comparative instrument for assessing the changing place of scientific concepts in society. If that resembles the kind of research many of us are already doing, then all the better. The next step is to move our critical discourse beyond the confines of the literary academy and into the public policy arena.

In the case of Collins, there are several specific conclusions that one might draw from juxtaposing his vision of the heritability of acquired characteristics with that proposed by advocates of epigenetics. Epigeneticists think that study of the nongenetic sources of human inheritance might have a number of desirable social consequences. To begin with, knowledge that one's genome is not the only source of developmental traits or heritable attributes might undermine genetic determinism, the widespread belief that one's character is written in one's genes. As the editors of the special supplement of Nature put it, the field may be 'an antidote to the idea that

we are hard-wired by our genes. ${ }^{21}$ Jablonka and Lamb hold out a similar hope. They argue that molecular studies will help discredit the idea that 'there is a gene for adventurousness, heart disease, obesity, religiosity, homosexuality, shyness,

19: Interdisciplinary Studies in the Long Nineteenth Century, 7 (2008) www.19.bbk.ac.uk 
stupidity, or any other aspect of mind or body. ${ }^{22}$ Additionally, they suggest that epigenetics will challenge the popular conception of evolutionary psychology, in which human behaviour is always referred back to adaptive evolution in the prehistoric past. Since 'epigenetic variations are generated at a higher rate than genetic ones, especially in changed environmental conditions,' they believe that people are able to adapt to altered life circumstances on a far more rapid scale than traditional, gene-cantered evolutionary psychology would allow. ${ }^{23}$ Finally, they maintain that epigenetic evidence that evolutionary variation may be directed rather than purely random does not entail believing in a purpose or teleology to evolution, nor does it give support to intelligent design.

Attractive as I find all of these conclusions, I do not think they follow inevitably from a change in research paradigms away from genetics and toward epigenetics. The social consequences of a scientific development depend on how the culture at large understands the research and what its attitude is toward the science. The example of Collins shows that the public could well view results that proved the heritability of acquired characteristics as powerful new arguments for determinism and that cultural presumptions about gender (and other issues) may well outweigh what people know about science. Equally, Galton had no trouble reconciling his concession that embryonic and pre-embryonic nurture played a role in shaping character with a eugenic program focused entirely on males. Finally, while neither Collins nor Galton were tempted to see the hand of an intelligent designer in adaptive evolution, many other people in the 1880 s were eager to draw exactly that conclusion - as they are today.

Jablonka and Lamb explicitly reject an intelligent-design interpretation of their results, but scientists rarely have control over how their findings are interpreted. Literature, drama, the arts, media, popular culture, religious discourse and countless other forces play roles in shaping how such research is understood. Although I am not so foolhardy as to believe that literary studies can guide the way in which our society dreams its scientific dreams or shudders at its technological nightmares, I do believe that we have a valuable perspective on such matters, which could be of benefit to public policy decisions. 
In the wake of genetic and epigenetic discoveries of enormous power, we find ourselves faced with a situation comparable to that Collins encountered in the 1880s, when evolutionary theory was unsettling many things Victorians held dear. In the Victorian era, literary figures may not have been clear-sighted in every case, but at least they were confident that their words joined in dialogue with those of scientists such as Galton, Huxley and Weismann, whose vision, after all, was not always pellucid about the social consequences of evolution. Although the institutional framework that enables humanists to participate in science policy today is entirely different from that which prevailed more than a century ago, the opportunity exists once again. Those of us interested in how culture shapes understandings of science should consider how we will respond to this opportunity. ${ }^{24}$

\section{Endnotes:}

\footnotetext{
${ }^{1}$ Adrian Bird, 'Perceptions of Epigenetics', Nature, 447 (24 May 2007), v, 396-98 (p. v).

2 Alex Eccleston, Natalie DeWitt, Chris Gunter, Barbara Marte and Deepa Nath, 'Epigenetics', Nature, 447 (24 May 2007), p. 396.

${ }^{3}$ Eva Jablonka and Marion J. Lamb, Evolution in Four Dimensions: Genetic, Epigenetic, Behavioral, and Symbolic Variation in the History of Life (Cambridge, MA: Massachusetts Institute of Technology Press, 2005), p. 1.

${ }^{4}$ The remainder of this section is adapted from my article 'Victorian Chimeras, or, What Literature Can Contribute to Genetics Policy Today', New Literary History, 38 (2007), 569-92.

${ }^{5}$ For more on the 'undisciplined' culture of the nineteenth century, when science and the humanities were not as thoroughly segmented into disciplinary specialties, see chapter 3 of my book Charles Dickens in Cyberspace: The Afterlife of the Nineteenth Century in Postmodern Culture (Oxford: Oxford University Press, 2003).

${ }^{6}$ Bill Readings, The University in Ruins (Cambridge, MA: Harvard University Press, 1996), p. 82.

${ }^{7}$ President's Council on Bioethics (17 January 2002). For a transcript of this discussion, see 'Science and the Pursuit of Perfection: Discussion of Nathaniel Hawthorne's Short Story, "the Birth-Mark", <http://www.bioethics.gov/transcripts/jan02/jan17session2.html> [accessed 15 April 2008]

${ }^{8}$ Literature, Film, and Genetics at <http://www.literatureandgenetics.org/>.

${ }^{9}$ Wilkie Collins, The Legacy of Cain (1888; repr. McLean, VA: IndyPublish.com, [n. d.]), p. 237. All further quotations from the novel will be noted parenthetically in the text as $L O C$.
}

\section{Jay Clayton, Inherited Behaviour in Wilkie Collins's The Legacy of Cain: Victorian} Studies and Twenty-First-Century Science Policy

19: Interdisciplinary Studies in the Long Nineteenth Century, 7 (2008) www.19.bbk.ac.uk 
${ }^{10}$ See, for example, Robert Ashley, Wilkie Collins (London: Arthur Barker, 1952), pp. 120-21 and William H. Marshall, Wilkie Collins (New York: Twayne, 1970), pp. 106 and 114.

${ }^{11}$ August Weismann, 'On Heredity', in Essays Upon Heredity (Oxford: Clarendon Press, 1889), pp. 67-105 (p. 104). All further quotations from this essay will be noted parenthetically in the text as $\mathrm{OH}$.

${ }^{12}$ Marshall, p. 114.

${ }^{13}$ Jenny Bourne Taylor, In the Secret Theatre of Home: Wilkie Collins, Sensation Narrative, and Nineteenth-Century Psychology (London: Routledge, 1988), pp. 237-38.

${ }^{14}$ Taylor, p. 138.

${ }^{15}$ Christopher Kent, 'Probability, Reality and Sensation in the Novels of Wilkie Collins', in Wilkie Collins to the Forefront: Some Reassessments, edited by Nelson Smith and R. C. Terry (New York: AMS Press, 1995), pp. 53-74 (pp. 61 and 64).

${ }^{16}$ See the intellectual context section of the Broadview edition of Collins's Heart and Science, edited by Steve Farmer (1883; repr. Peterborough, Ontario: Broadview, 1996).

${ }^{17}$ Francis Galton, Inquiries into Human Faculty and Its Development, 2nd edn. (London: Dent, 1907), p. 168.

${ }^{18}$ Galton, p. 131. I thank my colleague Natalie Champ for drawing my attention to this passage.

${ }^{19}$ See Eva M. Neumann-Held and Christoph Rehmann-Sutter (eds.), Genes in Development: ReReading the Molecular Paradigm (Durham, NC: Duke University Press, 2006).

${ }^{20}$ Leon R. Kass, 'Being Human: An Introduction', in Being Human: Readings from the President's Council on Bioethics (Washington, DC, 2003), pp. xvii-xxv (p. xvii).

${ }^{21}$ Eccleston, et al., p. 396.

${ }^{22}$ Jablonka and Lamb, p. 6.

${ }^{23}$ Jablonka and Lamb, p. 144.

${ }^{24}$ Research for this article was supported by a grant from the National Institutes of Health, \#R03HG3031-2. Many thanks to Lauren Wood Hoffer for her expert research assistance on this article. Studies and Twenty-First-Century Science Policy

19: Interdisciplinary Studies in the Long Nineteenth Century, 7 (2008) www.19.bbk.ac.uk 